\title{
The Effects of Transaction Costs on Investor Sentiment: Evidence from the Nigerian Electricity Service Industry
}

\author{
Omoleye 0juri* and Olu Morgan \\ Bartlett School of Construction and Project management, University College London, UK
}

Submission: June 17, 2019; Published: July 09, 2019

*Corresponding author: Omoleye Ojuri, Bartlett School of Construction and Project management, University College London, UK

\begin{abstract}
Privatisation of the Nigerian Electricity Service Industry represents a bold first step on a multi-dimensional journey to social and economic development. Significant challenges remain to be overcome. This paper examines the reforms through the lens of New Institutional Economics in order to determine how weak institutions have so far confounded seasoned local investors and international advisors, by looking for the presence of excessive transaction costs. The reform environment is based on Williamsons 4 levels of social analysis and subjected to evaluation based on four areas deemed critical for reform success, namely property rights, market structure, conflict resolution mechanisms and policy implementation capabilities. The study is restricted to investors in electricity distribution companies, and the presence of high transaction costs used as proxy for institutions in need of further improvement. The study finds that providing quality asset performance data and changing a culture that tacitly accept electricity theft and late bill payment, will reduce the transaction costs associated with defining and protecting Investors property rights. However, the regulatory environment must mature to enjoy the confidence of government, consumers and investors, who continue to remain optimistic.
\end{abstract}

Keywords: Electricity Market; New Institutional Economics; Transaction cost

\section{Introduction}

The availability of quality infrastructure is a vital factor in a country's economic growth and development [1]. Adequate electricity infrastructure remains pre-eminent within the asset class; primus inter pares because of its social and economic impact on the modern nation state. Electricity is non-substitutable and massively consumed [2]. Production and distribution are characterised by significant environmental externalities. Provision and pricing has, and continues to be of concern to the general public, and subject to interference and reform by legislators and regulators. The publically owned Nigerian Electricity Service Industry (NESI) was a government failure following decades of economic mismanagement exacerbated by criminal vandalism [3]. The government recently embarked upon a programme of long-term structural change in line with the standard textbook model, centered on regulatory reform and privatizing legacy power assets. In addition to the creation of NERC, the regulator, reforms entailed horizontal and vertical disaggregation and subsequent privatization of the generation and distribution elements of what was a vertically integrated public monopoly [4] while transmission continues in public ownership.

After a slow start, implementation of reforms gathered pace in 2010, with extensive international support coming from the UK government (DFID, 2014). By 2013, almost exclusively supported by local banks and investors, Africa's largest power privatisation programme was complete and lauded a success by international observers, including multi-lateral development institutions such as the World Bank. By 2017 however, the government power sector recovery programme had identified several challenges which 'created the need for a 'market reset' [5]. Extensive literature including [2,6-14] evaluate the status of electricity reforms in developing countries which has also been described as one of mixed outcomes, stalled reforms, and uncertainty [15]. Similarly, the varied progress of power sector reform between countries has been the subject of much study with dissimilarities at both national and sectorial levels deemed attributable [13]. The overarching conclusion is that long run reform success requires a balance between allocation issues such as price, tariffs and subsidies; and a supporting institutional framework [16].

Suggest that while acknowledged in the literature [14] institutional factors are seldom given in the reform process. The approach taken is often to reshape the institutional setup in order to improve efficiency or similar distributional aspects of economic activity. And while most technical and economic charac- 
teristics of the reforms have been studied, there is little evidence to show that the institutional framework has been explored. And here, the principal area of interest. How have the institutional factors at play within NESI managed to confound a knowledgeable community of international advisors and local Investors? Unquestionably, a full review of the entire industry reform is beyond the scope and the time available for this study. Thus, the focus is narrowed to the perspective of DisCo Investors, whose are considered essential to be essential for overall industry success. The key issue identified under the PSRP is for sufficient DisCo revenues to meet their market liabilities, operating costs and capital investment requirements [5]. The theories that sit within the framework of New Institutional Economics (NIE) provide a linkage between institutions, property rights and transactions costs [17]. Institutions evolve to reduce transaction costs so that property rights can be defined, allocated and exchanged at minimal cost. Thus, institutions have a role to play in reducing transaction costs in order to maximize the gains from economic exchange. From a different perspective, high transaction costs will dissuade investor's and lead to market failure of reforms. Supporting research looks for where Investors experience high transactions costs as an indication of failed or non-supporting institutions and will endeavor to answer the following specific questions:

1. Which factors within the NESI reforms contribute to excessive transaction costs?

2. What is the impact of these transaction costs on the business of NESI Investors?

3. How does the prevalence of these costs affect investor sentiment, particularly in relation to further investments under the current market structure?

The value of this study derives from both its timing and its geographic focus. It comes at a critical time when major financial interventions are planned by Government and the World Bank in response to the poor performance of the reforms to date. By geography, the focus on Africa's most ambitious electricity reforms provides a country specific contribution to the body of literature concerned with institutional constraints on infrastructure development. Nigeria's has a significant potential to contribute to global instability because of its chronic lack of infrastructure and poor economic development but will in the space of few short decades become the 3rd most populous nation in the world [18]. Investors are a critical component within any private sector-oriented market reform. The scope of the research covers the current Investors in the NESI Dis Cos. This includes equity Investors, lending banks, transaction and legal advisory and senior management persons. Surveys are restricted to private investors only, recognizing that State governments are minority shareholders in some of the privatized companies. Institutional investors do not feature. The public entity that operates the transmission network and the bulk trader and the regulator, NERC are also excluded. Given the multiple perspectives in play, it is recognised that these excluded entities, or other industry stakeholders (e.g. customers, government, etc.) might well provide a contrasting picture. The rest of this paper is organized as follows. Section 2 undertakes literature review in order to position the NESI reform within a NIE framework. Section 3 discusses the methodological approach taken to progress the research, Section 4 presented the findings, and Section 5 concluded the paper

\section{Literature Review}

\section{New Institutional Economics (NIE)}

Neoclassical economics has a non-institutional approach to economic analysis $[19,20]$. It assumes that the basic underlying institutions necessary for economic analysis, e.g. private ownership, credible property rights, enforceable contracts, and well-functioning corporate governance systems and markets are given. Firms were simply production functions, a black box governed by economics of scale. Only trivial explanations of vertical integration existed. The differences in economic growth between countries was poorly understood [21] and the influence of government institutions on the same was largely ignored. Critically, the application the existing theory to developing countries was challenging, particularly as there was no way to accommodate the idiosyncratic and unmeasured attributes of social, political and economic institutions between countries [22].

The efforts of economist who sought to address the shortcomings of orthodoxy led to a growing school of thought which eventually became known as New Institutional Economics [23]. Beginning with the premise that institutions matter and must be predisposed to analysis [24,25] NIE combines economics, law, organisational theory, political science, sociology and anthropology to understand social, political and commercial institutions [26]. Institutions are the regularities in repetitive transactions between individuals [27]. They are not persons, but the customs and traditions that provide a set of incentives and disincentives for individuals. Institutions arise and evolve because of the interactions between individuals. Within the institutional framework, individuals form organisations to capture the gains arising from specialisation and division of labour.

Analytical framework illustrating NIE is commonly used [25]. It describes institutions at 4 overlapping levels of social abstraction. Feedback mechanisms exist between the levels, but progress at the lower levels (L4 lowest) is constrained by progress at the higher levels (L1 highest). NIE is concerned with L2 \& L3 [21] slightly modified illustration is shown in Figure 1. Contextualized for the NESI reforms, we have as follows:

\section{L1 - Social embedment level}

This is where Nigeria's history and culture as a people (Yoruba, Hausa, and Ibo etc.) and its historical beliefs (chieftaincy traditions) and religion (Christianity, Moslems, and Pagan wor- 


\section{Civil Engineering Research Journal}

ship) lie. The core social and cultural institutions that exist here change very slowly and have evolutionary cycles that stretch into hundreds or even thousands of years. This level is taken as given.

\section{L2-Institutional environment level}

The basic institutional level of what Williamson calls the rules of the game. According to Joskow [21] this level includes the governing constitution encompassing the political system and basic human right; definition and allocation of property rights, and legal laws and institutions to enforce political, human rights and property rights, and the governance of money. This includes basic financial institutions, taxation powers, governance of migration, trade and foreign investment and, the political, legal and economic administrative competencies that facilitate change.

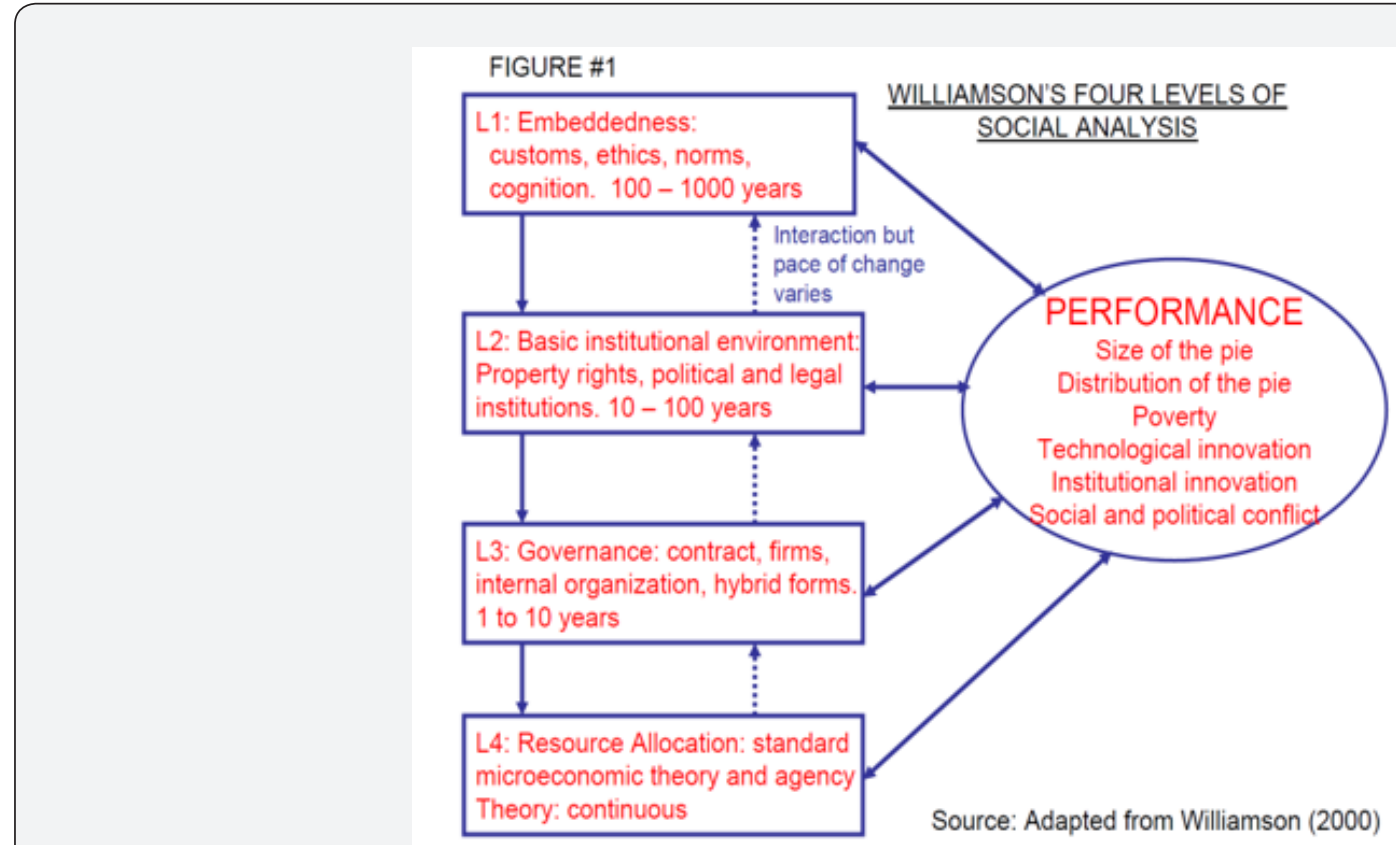

Figure 1: Williamsons 4 Levels of Social Analysis Williamson [25].

\section{L3-Institutional arrangements (governance) level}

Williamson calls this 'The play of the game'. Here resides the choice of arrangements that govern the conduct of economic relationships-the basic framework through which economic agents' trade goods, services and labour evolve. The boundaries for the nature of transactions that will take place in the market and those that are internalized within the firm emerge, defining the horizontal and vertical boundaries of the firm. Contracts are managed as economic actors adapt and align under a discriminating alignment from markets to hybrid to hierarchy governance structures responding to asset specificity, uncertainty and frequency. Corporate governance and functioning of financial institutions that provide credit support for private investment emerge. The key institutions of interest regarding the NESI reforms include regulatory, commercial, and consumer markets. Ultimately, the choice of governance arrangements is predicated on the institutional environment as well as the basic economic conditions that pertain such as the presence of natural resources etc. The pace of change is faster than witnessed in the environment level above, and a time frame of between 1 and 10 years is suggested.

\section{L4-Individual level}

Here the usual neoclassical economics provisions that govern the day to day functioning of the economy applies, con- strained by the institution's established by the three preceding levels. Production, resource allocation and employment, labour supply and consumer's rights etc. are governed under the rules of price, demand and supply, agency theory. The evolution is continuous, with prices and production are more or less continuously adjusted.

\section{Property Rights, Transaction Costs and Institutions}

NIE owes much to work of Ronald Coase who made the critical connection between institutions, transaction costs and neoclassical theory $[19,27]$ links the institutional environment back to 'The Problem of Social cost' [28] and Governance back to 'The nature of the Firm' [29]. Transactions Costs derive from weakness in the contractual situation; brought on by the human conditions of bounded rationality and thus contractual incompleteness, and the potential hazard of opportunism. Ex ante TC's arise from attempts to prevent transaction failures due to asset specificity and opportunism, including drafting, negotiating and safeguarding a contract. Ex post TC's are the costs of altering contracts to correct ex post misalignments, the costs of setting up and maintaining governance structures and the costs of bonding to guarantee contractual commitments $[17,24]$. Highlights that transaction costs not only exist but also [17] they are huge and may represent about $50-60 \%$ of net national product of modern market economies. In less developed economies, 


\section{Civil Engineering Research Journal}

transaction costs are thought to make up an even greater fraction of the overall GDP and frequently deter exchange. Within the governance branch of NIE, [30,31] extend Coase's insight through Transaction Cost Economics [32]. A rational discriminating alignment matches the choice of governance form (markets, hybrid, and hierarchy) with the dimensions of transactions factors (asset specificity, uncertainty and frequency) in order to reduce transaction costs. North takes a different approach and focuses on the institutional environment. He argues that institutions emerge in order to minimise the informational costs of transacting, brought about by the same failing of human agents. Institutions evolve to lower costs so that the gains from exchange are once more possible.

Suggest that the traditional [33] TCE governance approach needs to be adjusted so it can be successfully applied to developing countries since it partially ignores the role of governmental policies and institutional change. Thus, a combination of the Williamson and North approaches is required to take into account both power relations and incentive dynamic structures. Property rights are the keystone of an economic system. It provides the basis for trade and a market economy, defining the use, income rights and transferability of assets and therefore plays a central role in economic development [34,35]. Establishing and maintaining property rights entail transaction costs [17]. When transaction costs are substantial, the allocation of property rights becomes critical to the point where economic exchange is no longer desirable. Maintaining Property rights requires third party enforcement, hence the rule of law [24].

Any school of thought that addresses the role of social, cultural, political and economic institutions on economic behaviour will inevitably have its detractors. NIE is just as much criticised as it is supported, whether directly [36], or via transaction costs theory [37]. One weakness of NIE is that it cannot explain how to overcome path dependency. While Institutions may be important determinants of economic performance, when it comes to new general insights about how that determination works, the NIE adds nothing to what is already known. No new predictions are derived; no new policies are recommended [38]. Opponents of the Transaction cost theory school include [39] who suggest that the TCE concept cannot provide a sufficient rationale explaining either the emergence of institutions or the origins of organisations given it static, ahistorical and universalistic nature. Being that a substantial body of Nobel Prize winning economists' lies on the side of the theory, no further discourse into these critics is attempted.

\section{The Electricity Service Industry (ESI)}

Market oriented reforms such as that envisaged for NESI calls for institutional arrangements that support the private sector participation. This affects market instruments such as property rights, information and prices [16] which are in turn also determined by a combination of proposed market structure and the underlying industry characteristics. The following key fea- tures of the ESI are noted (Alves de Santana \& da Silva Leite n.d.), $[21,22,40-45]$. Firstly, Economies of scale exist in the 3 segments of production, transmission and distribution. Large, lumpy, irreversible upfront infrastructure investments in generating plants, transmission lines and distribution networks deliver decreasing average costs. Secondly, Electricity is a homogenous good that cannot be economically stored but is yet subject to varying temporal demand. Thirdly, the direct physical relationship between a specific generator and a specific customer and no economical way to curtail an individual customer's consumption when specific generators fail to perform. Fourthly, the aggregate shortrun elasticity of demand is inherently small and the effective short-run elasticity of demand further reduced by the absence of hourly metering, communications, and pricing arrangements. Fifth, efficient electricity pricing can only be achieved if prices signalled to producers and consumers reflect costs by time and location. Sixth, the physical and technical attributes of the AC networks which contribute to the potential network externality and network "commons" problems also make is difficult to define a well-defined set of property rights.

The forgoing suggests that the electricity sector should be structured around large firms, behaving as natural monopolies [16]. The economic logic is that the operational and investment relationship between generation and transmission is more efficiently internalised within a single entity, where an internal operating hierarchy is more efficient than market. The success of the Chilean reforms demonstrated that alternative market arrangements were possible, and the right institutional setup is able to induce investment and expansion [16]. Thus encouraging the reform bandwagon. But paradoxically, it would appear that the degree of disintegration that is economically efficient is no longer obvious, contrasting with the neo-classical perspective on which the anti-trust arguments favouring vertical disintegration were based [46-49]. As a case in point, Meyer [50,51] reports permanent cost increases of up to $20 \%$ when generation is un-bundled from retail and finds scant evidence to support the legal arguments that vertical integration leads to economically inefficient market power. Michaels [48] found that utilities enjoy strong economies of vertical integration.

\section{Institutional Perspective on Electricity Reform}

Erdogdu [10] finds that while there has been a substantial body of work investigating various aspects of institutions, there is no evidence of earlier empirical work that applies the NIE approach to the analysis of power market reforms. However, the earlier work indicates that NIE has a valid contribution to electricity market reform including that

\section{Institutions matter,}

2. The neoclassical ideal assumptions need to be abandoned in favor of the reality posited by NIE,

3. Institutions may be both an enabler and a constraint, 


\section{Civil Engineering Research Journal}

4. NIE establishes a fundamental relationship between property rights, transaction costs and institutions,

5. Nonmarket transaction costs are important

6. The electricity market reform is largely path dependent.

Note that while $[10,16]$ institutional factors are acknowledged in principle, they are usually not appropriately considered in the design of reform processes. To the contrary, institutional transformations are designed in response to the distributional aspects of the economic policy envisaged, and any feedback effects was often ignored. For example, market-oriented reforms would require institutional arrangements that support private sector participation. Bhattacharyya [7] proposes four key institutionally derived areas of the electricity reform process that affect the outcome significantly are

1. Stability of the political decision-making system

2. Overall acceptance of the rules of the game

3. Ability to adapt to the changed environment

4. Proper transition period management

Studying the effects of institutional aspects on Investors partly follows [16] choice of four areas that are deemed critical to success, namely property rights, market structure, conflict resolution mechanisms and policy implementation capabilities. Allocation and protection of property rights is essential for success of private (majority) ownership of generation and distribution. The post reform market design is critical for the implementation and operational success of the reforms, including not only the regulatory aspects, but of the structures of roles and incentives that are deemed to be necessary for long run success. Formal and informal conflict resolution mechanisms are necessary for implementation and long-term operations, help to enforce standards and the competitive behaviour expected from market design. The combination of market design and conflict resolution, and most importantly, the capacity of regulators to present a consistent set of policies that avoid the capture by politics, vested interests and detractors and encourages all parties to work together for success. The last three of these key elements are considered to be critical for institutional issues that affect investor sentiment.

\section{Methodology}

Given the research focus, a qualitative method was applied to collect information in order to gain an understanding of investors' attitudes. Fellows and Liu [52] state that the qualitative approach seeks to find out why things happen as they do; to determine the meanings which people attribute to processes. From this, theories will emerge Oakley (1994). Analysis of qualitative data falls into a number of categories [53].

1. Theory-building-seeks to develop theory out of the data collected during the study
2. Descriptive or interpretive attempts to develop a coherent view of the subject material.

3. Language based-understanding the environment and interpreting intent.

Data was collected from primary and secondary sources. Primary research was used to gather the data through semi structured interviews with Investor representatives. The interviews were conducted in Nigeria between July and August 2018. In total, 14 people were interviewed, a cross section of Equity Investors and senior persons from electricity generation and distribution companies, lending banks and transaction and legal advisory services. Most interviews were held face-to-face and lasted approximately one and a half hours and recorded in whole or in part - subject to consent. In applying qualitative analysis approach, first, the data was coded using the NVIVO-11 qualitative software. The coding was conducted on the transcribed interviews for the purpose of identifying keywords and phrases that would give understandings and meaning to the data collected. In order to generate themes and in search of patterns that suggested relationships or common themes, the codes were assigned a "free node" where coding was unstructured and hundreds of codes were identified, thereafter were collated into "tree node".

The next step was the use of thematic coding. In addition, with NVivo 11, the researcher was able to get a broad feel for different types of themes available in the data. The researcher ran a quick word frequency to see which words the respondents used most frequently. This resulted in word cloud that brought about emerging themes which also groomed the themes to check whether related themes could be grouped together. The most important thing the researcher did was to stay focused on the research questions including the design. The research questions form the basis of the semi-structured interviews. The primary purpose of the questions is to stimulate discussion, and allow the interviewees to elaborate on the rational and approach of Investors during the bidding process in the run up to market entry, the challenges encountered in operating at market since privatisation, and their perceptions about the future direction of the industry.

\section{Findings}

This section highlights some of the key issues identified from interviews with Investors under the thematic areas previously discussed, these being property rights, market structure, policy implementation capabilities and conflict resolution mechanisms. It should be noted that in practice, these themes have a considerable overlap in L2 and L3 institutional features, and matters discussed are significantly interrelated.

At the heart of the NESI reforms is a significant liquidity problem [5]. However a common observation is that many of the issues faced by Investors flow from the availability and quality of information and how evolution of the underlying institutions and organisations that deliver the reforms are shaped by and react to information issues. 


\section{Civil Engineering Research Journal}

\section{Property rights}

Defining and protecting investor's property rights, particularly in the case of the Dis Cos have a significant impact on the profitability of the industry, and on the financial viability of the entire NESI. Here Investors suffer significantly in two keyways. Theft of electricity service is a significant issue in a country where their electricity tariffs have historically been below the cost of supply, most consumers were not metered and have been used to paying a token flat rate that does not reflect the quantum of electricity consumed. In fact, in many quarters, electricity supply is considered to be a social good which ought to be free or subsidized by FGN. Theft is only recently beginning to enjoy the support of formal law enforcement. Therefore, Investors find unexpectedly high cost associated with revenue collections (commercial and collection losses account for up to $32 \%$ of electricity supplied [4] and at the same time face complaints about overbilling from unmetered customers who are currently charged a flat tariff regardless of consumption.

Energy theft, over-billing and the non-payment of electricity bills are all related to the historic problem of a lack of metering of consumers. In the lead up to privatization, PHCN successor companies failed to extend metering significantly, and relied extensively on estimated billing in order to meet the high revenue targets they had been set (presumably such revenue targets being required to inform the coming privatizations. The Dis Cos have maintained this practice, which understandably remains unpopular particularly in the face of increasing tariffs.

Pre-payment meter installations programme significantly lags the Purchase Agreement requirements and there is increased pressure on Dis Cos to accelerate. However, not only do Investors complain that the tariff structure makes insufficient provision to recoup the necessary investment, Dis Cos have to deal with customers who do not buy electricity for months on time partly due to lack of power supply, but allegedly due in large part to bypassing their meters. Some power distribution companies are now installing smart meters that are better able to determine if their customers are cheating but such meters are more expensive than allowed in the tariff. Thus, Investors have a concern that as more customers move to a prepaid metering system it will increase the losses from electricity theft. Further, there is a complex social interaction between the price and consumption of electricity. As previously unmetered consumers realise the real cost of electricity consumed they either cut back on consumption or increase theft of service. The Dis Cos sells less and incur additional costs in protecting its property rights. Both push up the unit price of supply which has to pay for capital and operational costs. Finally, the institutional challenge is brought into sharp focus by Government Ministries, Departments and Agencies (MDA's) who do not pay their electricity bills and constitute the single largest debtor group to the industry $\$ 206$ million at the end of 2016 [5] Some Investors claim that up to $70 \%$ of electricity supplied is consumed by non-paying MDA's. Not only does this set a poor precedent for domestic consumers, the more recent tariff proposed by NERC, (indeed the settlement scenarios put forward under the recent recovery plan) simply assumes that MDA debts will be paid-without specifying how.

\section{Market structure}

Reform envisages that a competitive wholesale market will emerge in due course. For the time being the privatized Gen Cos and Dis Cos have to deal with a TCN, Bulk trader and System Operator that still public sector owned and operated. Investors contend that the biggest issue with TCN is load rejection even as TCN contends it is the Dis Cos that reject power. The dilapidated transmission and system control infrastructure is not able to deliver power to the specific location where the Dis Cos require it, such demand in quantum and location being driven by Dis Cos preference to prioritise credit worthy customers, since power supplied otherwise becomes their liability. TCN infrastructure is also constrained where Northern supply is concerned, with insufficient wheeling capacity. Since the tariff is based on a certain minimum level of supply, Dis Cos suffer financially when insufficient power is supplied, and incur additional liabilities on the part of TCN. In order to reassure Investors, an independent international company, Manitoba, was appointed to manage TCN, pursuant to efficiencies, best practice and effective investment deliver, subject to government funding. Reportedly, Manitoba never had the authority or the resources to discharge its contract effectively and management of TCN returned back to the Public sector in 2016.

The Gen Cos have a vesting contract with NBET and consequently the challenges of the industry sit within those contracts. NBET would like the Dis Cos to increase the thresholds of their remittances which had fallen to $29 \%$ by 2016 (53\%, 2015) [5], but this is unlikely given the existing cash shortfall. The perception across the industry is that the Dis Cos are 'cooking the books'. Dis Cos reject this and maintain that the shortfall is not just a collections issue, but a structural and commercial issue across the entire industry 'You can't give away money when you don't have it'. Further distrust across the industry has arisen over the last few months with allegations that Gen Cos are inflating their invoices. Relationships across the market is poor. The commercial performance at either side of the publically held bulk trader divide has a major impact of cash flow across the entire industry, and the mitigating effect of NBET, designed to ensure liquidity until a fully functional TEM is achieved is no longer adequate in the face of massive financial deficits.

\section{Policy implementation capabilities}

Government sent all the right messages at privatisation. Regulation and transaction agreements were designed to make government a junior partner and encourage Investor ownership. Privatisation was fair and the operations requirements clear. Disco investors assessed the market and negotiated a tariff which was regularly reviewed. They are held to a set of performance requirements, and if they fail to perform over a period of time, assets revert back to government for one dollar. But so 
long as requirements are met over the 5-year period, Investors can return to market under an IPO and bring on board even more investors and the government divests of its own holding. Investors would have conceived that risk was appropriately distributed. Interviewees confirmed that formal the bidding process was conducted appropriately, transparently and that the international bodies including the World Bank who provided monitoring were satisfied. There was no evidence of cronyism. However, due diligence by bidders was limited to the Vendors data rooms, which was felt to contain insufficient data about the operational state of the assets or critically, analysis supporting ATC\&C losses. It was noted for example that NERC's estimation of ATC\&C losses was in the region of $20 \%$, even NERC's independent consultant suggested that $30 \%$ was a more realistic figure. Physical inspection of the assets was limited by hostility from the Electricity Union Workers during the period of the sale, and the 6 month transition period prior to hand over of assets prevented by the same. As such Investors business plans was based on the information provided by the seller's representative; the Bureau of Private Enterprises (BPE), an arm of government which also now sits as the minority shareholder on the board of the privatised companies.

While commercial evaluation for the Gen Cos was on the basis of the bidder's purchase price, Dis Cos tender evaluation was based on the ATC\&C loss reduction model, a theoretical construct that measures the efficiency and effectiveness of a distribution company. This permits Vendor setting of fixed price (valuation) for the asset, while the bidders bid a business plan that maximizes ATC\&C loss reduction over a 5 year period. The winning bid for a given DisCo is maximum periodic reduction bid. The potential problem with this methodology includes:

1. Measurement of ATC\&C remains data driven and highly subjective in the absence of metering and accurate customer database.

2. There is a relationship between ATC\&C and MYTO, which stipulates annual capex and opex requirements, approved rate of return and other Dis Co expenditures.

If the ATC\&C loss reductions bid is out of step with MYTO investment provisions, then an investment deficit results. It is almost certain that any bidder who prevented this investment deficit would have lost out at bid. At the same time, it is not certain how a bid proposal that willfully destroys its equity base can be credible to lenders or the regulator, or sustainable in the long run. However, this appears to have been the basis of many of the winning bids. Unsurprisingly, there turned out to be a gulf in asset and enterprise condition between pre and post-sale reconciliations by the new owners. Some of the interviewees went as far as to suggest a willful misrepresentation of the facts. Actual average losses on takeover averaged 46\% [4]. And whilst this might have had an impact on baseline asset valuations, it had a much more significant impact on the operational business plans on which the bids were based and therefore, the rate at which notable improvements could be affected. More investment is required than anticipated, and a greater rate in order to meet the asset improvement trajectories on which the tariffs were based. And this could only be achieved by a corresponding increase in cash flows, and thus tariff in the absence of further debt or equity injections.

It evident that Investors clearly under-estimated the challenges of the power sector during the bidding process, but the method of evaluation ensured that the greater the degree of optimism, the greater the chance of winning. Further it appears that privatisation was underpinned by unrealistic assumptions by NERC. E.g., expectations was that Dis Cos would be able to remit 90 percent of their market invoices to NBET by 2015 (actual emittances was only 53\% in 205 and has fallen even further in 2016), meaning that when combined with the short term liquidity provision from NBET, the industry would have always generated sufficient cash flow. Indeed, there was an expectation that there would have been break-even midpoint of the first five year cycle and certainly no later than the 3 year, including allowance for capital program induced efficiencies. Consequently, insufficient emphasis was placed on the medium to long term financial capability of Investors, who were mostly highly leveraged. With actual invoice remittances is less than half the anticipated levels, it is not surprising to see how the severe financial deficit across the industry has developed.

Despite the high levels of initial interest, local Investors sensed early on that international Investors, including banks would not participate in the privatisation. Four implementation issues were identified as making the industry un-investable by international standards:

1. Lack of cost reflective tariff.

2. Lack of sanctity of contract - following poor experiences on previous PPP's.

3. Regulatory uncertainty.

4. Lack of investment by local pension organisations of the host country.

It is suggested that some local Investors having a lack of knowledge of the sector may have been blinded by their belief that the power sector would be another communications boom. But this is thought to represent only a small minority and the overwhelming perception was that local Investors considered that the potential institutional failings could in the fullness of time be overcome.

\section{Conflict Resolution Mechanisms}

The core issues at the heart of the NESI reform are cost reflectiveness, regulatory uncertainty, policy consistency, protection of sanctity of contract. These need to be addressed in order to realize the kinds of turnarounds expected in the sector. Regulatory uncertainty remains the biggest challenge from an investor perspective, and is also the biggest risk on lenders books, 


\section{Civil Engineering Research Journal}

meaning that no lender will lend to provide further capital investment. Investors recognize that informal conflict resolution begins with the regulator. Formal resolution continues with the regulator followed by, the judiciary, and then the government. But there is little appetite for judicial intervention. Recently, consumer groups bypassed the regulatory process and obtained court injunctions over tariff issues. These were seen as extremely harmful to the industry and courts have been asked to refrain from intervention, until the regulatory process is exhausted. But whilst desirous of a productive relationship, Investors consider that the Regulator is neither independent nor apolitical. Part of the problem of politicization has been that the massive investments required for turnaround have not been recognized by the regulator who have made assumptions about significantly less CAPEX in the tariff calculus. A year of dispute after some Dis Cos collectively triggered force majeure notices on the back of inconsistent and incoherent regulatory rulings have only recently been resolved by government. The evolving NERC framework for Business Continuity in NESI is perceived by Investors as tantamount to re-nationalizing the assets and viewed with dismay at a time when all stakeholders should be working towards constructive solutions. The PSRP is a step forward and seen by investors as indicative of the government finally attempting to get its own house in order and recognize how investors have been let down. But it does not address robustly the issue of regulatory uncertainty. There is also a need for better risk allocation across the value chain and for the government to take ownership of major elements of risk that are unique to it such as forex, gas pipeline vandalisation, macro-economic issues, regulatory issues and MDA debt [53-66].

The case of forex is highlighted in particular. $75 \%$ of industry costs are dollar based, and Investors saw safety in minor tariff reviews which would be implemented as necessary. However minor reviews for June 2016, Dec 2016 and June 2017 remain outstanding. The current MYTO 2015 tariff was based on exchange rate of 198 Naira to the dollar. Current official rate is 303 Naira and the parallel market rate is 365 Naira. Shifts in exchange rate not being uncommon has major financial consequences on revenues. Government options for dealing with forex shocks is to implement the regular tariff reviews and design a subsidy that cushion the impact to consumers. A major decision is required on the part of government in this regard if the sector is to advance. Even though the PSPR advocates that a Forex facility has to be considered for the power sector, it can still only be based on the official rate, which remains subject to macro-economic shocks.

\section{Conclusion}

This paper employed the NIE framework to set out the relationship between institutions, transaction costs and property rights. Institutions evolve to reduce transaction cost, enhance property rights and therefore promote economic development. Soto [16] suggests that reforms should address the evolution of institutions in 4 key areas- Property rights, market struc- ture, conflict resolution mechanisms and policy implementation capabilities. Within these areas, the research is based on the community of Dis Co Investors, an endeavor to identify weak institutions by focusing on the role of transaction costs as considered by North (1986) and thus set out to determine: Which factors within the NESI reforms contribute to excessive transaction costs? What is the impact of these transaction costs on the business of NESI Investors? How do the prevalence of these costs affect investor sentiment, particularly in relation to further investments under the current market structure?

The study found that a lack of credible information about asset condition, and data to support the calculation of ATC\&C losses had created an unrealistic expectation over capital investment and revenue requirements. This was exacerbated by a socio-economic culture where electricity theft and non-payment of bills was tacitly condoned by government and consumers alike. Delineation and protection of Investors property rights became challenging, high commercial and collection losses ensued and contributed to a significant financial deficit across the industry. The challenges arising from a lack of information was then exacerbated by a Regulator that was neither independent nor apolitical. There was an inconsistent application of the rules of the game, particularly regarding the periodic reviews of tariffs in order to incorporate external shock brought about by Naira depreciation. Compromised capital investment and debt service are inevitable in the face of 55\% depreciation in income currency where more than $70 \%$ of cost are dollar based. The aversion of the government to expose consumers to further tariff shock appears to be in play, particularly as the immediate benefits expected from private participation (steady uninterrupted power) is not yet experienced by consumers. Yet someone has to pay, and the rules of the game says that investors have a limited exposure to this risk.

Practically all Investors interviewed consider that Nigeria remains a good place to invest in power infrastructure. The demand for power remains significant. Unrealized demand due to businesses that have temporarily relocated to surrounding countries with less challenging production conditions represents a larger market still. The challenge is to find a way to balance the competing cash demands within the industry. Decentralisation, embedded generation, differential pricing, smart metering and data driven investment analysis are all part of the solutions suggested over the coming decades. Above all it requires a mature regulator that enjoys the confidence of both government and investors alike, and a government that has a more realistic expectation set.

NESI reform occupies a multi-dimensional space at the heart of the Nigerian economy. The danger with the limited scope of this dissertation is that an unbalanced view pertains, and the findings are not a true reflection of the key issues within the industry. There is some comfort PSPR recognizes that government and regulatory actions have materially impacted the performance of some of the more efficient Dis Cos especially in rela- 


\section{Civil Engineering Research Journal}

tion to tariff review [5] giving some credibility to the one-sided view presented here. A more accurate picture of institutional development will emerge from further studies with other stakeholders including Gen Cos, NERC, TCN, and SO. Given the time and availability of data, quantitative analysis of the industry performance would also support the measurement of transaction costs within the industry.

\section{References}

1. Weber B, Alfen H, Weber B (2010) Infrastructure as an asset class. Chichester, West Sussex UK.

2. Holburn GLF, Spiller PT (2004) Institutional or structural: lessons from international electricity sector reforms. In the Economics of Contracts: Theory and Applications. pp. 463-502.

3. Oseni MO (2011) An analysis of the power sector performance in $\mathrm{Ni}$ geria. Renewable and Sustainable Energy Reviews 15(9): 4765-4774.

4. FGN (2015) Ngerian power baseline report, Abuja.

5. FGN (2017) Federal republic of nigeria power sector recovery program: 2017- 2021, Abuja.

6. Jannuzzi GDM (2005) Power sector reforms in Brazil and its impacts on energy efficiency and research and development activities. Energy Policy 33(2005): 1753-1762.

7. Bhattacharyya SC (2007) Power sector reform in South Asia: Why slow and limited so far? Energy Policy, 35(1): 317-332.

8. Besant Jones JE (2006) Reforming Power Markets in Developing Countries: What Have We Learned? Pp.164.

9. Douglas JB (2006) Power Sector Reform in Developing Countries: A Return to Basics. The Electricity Journal 19(10): 63-70.

10. Jamasb $T$ (2006) Between the state and market: Electricity sector reform in developing countries. Utilities Policy 14(1): 14-30.

11. Erdogdu E (2012) A cross-country analysis of electricity market reforms: potential contribution of New Institutional Economics. Energy Economics 39: 239-251.

12. Kessides IN (2012) The Impacts of Electricity Sector Reforms in Developing Countries. The Electricity Journal 25(6): 79-88.

13. Sioshansi FP (2006) Electricity market reform: What has the experience taught us thus far? Utilities Policy 14(2): 63-75

14. Ullah K, Arentsen MJ, Lovett JC (2017) Institutional determinants of power sector reform in Pakistan. Energy Policy 102: 332-339.

15. Wamukonya N (2003) Power sector reform in developing countries: Mismatched agendas. Energy Policy 31(12): 1273-1289.

16. Williams JH, Ghanadan R (2006) Electricity reform in developing and transition countries: A reappraisal. Energy 31(6-7): 815-844.

17. Soto R (1999) Institutional reforms in the electricity sector. Graduate Program in Economics.

18. Musole M (2009) Property rights, transaction costs and institutional change: Conceptual framework and literature review. Progress in Planning 71(2): 43-85.

19. UN (2017) World Population propects. The 2017 Revision.

20. Williamson OE (1998) The Institutions of Governance. The American Economic Review 88(2): 75-79.

21. Agboola AO (2015) Neoclassical economics and new institutional economics. Property Management 33(5): 412-429.

22. Joskow P (2004) New institutional economics: a report card. Pp.1-32.
23. Joskow PL (2004) Electricity sector restructuring and competition: A transaction-cost perspective. In the Economics of Contracts: Theory and Applications. Pp. 503-530.

24. Williamson OE (1975) Markets and Hierarchies, The Free Press, New York, USA.

25. North DC (1986) The New Institutional Economics. Journal of Institutional and Theoretical Economics 142(1): 230-237.

26. Williamson OE (2000) The new institutional economics-Taking stock, looking ahead. Journal of Economic Literature 38(3): 595-613.

27. Klein PG (2000) New Institutional Economics. Encyclopedia of Law and Economic. Pp. 456-489.

28. North DC (1992) The new institutional economics and development.

29. Coase RH (2013) The problem of social cost. Journal of Law and Economics. Pp. 837-877.

30. Coase RH (1937) The Nature of the Firm. Economica 4(16): 386-405.

Johnson

31. Williamson OE (1981) The Economics of Organisation: The Transaction Cost Approach. American Journal of Sociology 87(3): 548-577.

32. Williamson OE (1979) Transaction-cost economics: The governance of contractual relations. Journal of Law and Economics 22(2): 233-261.

33. Allen DW (2000) Transaction Costs. Encyclopedia of Law and Economics. Pp. 893-926.

34. Saravia Matus S, Dietrich M (1990) Emergence and impact of transaction costs in developing economies: the case of the Nicaraguan coffee industry during the Sandinista Regime.

35. O'Driscoll GP, Hoskins L (2003) Property Rights the Key to Economic Development.

36. Eggertsson T (1990) The Role of Transaction Costs and Property in Economic Analysis. European Economic Review 34 (2-3): 450-457.

37. Bardhan P (1989) The New Institutional Economics and Development Theory: A Brief Critical Assessment. World Development 17(9): 13891395.

38. Hodgson GM (2010) Limits of Transaction Cost Analysis. He Elgar Companion to Transaction Cost Economics. Pp. 11.

39. Harriss J, Hunter J, Lewis CM (1997) The new institutional economics and Third World development. London, New York, USA.

40. Meramveliotakis G, Milonakis D (2010) Surveying the Transaction Cost Foundations of New Institutional Economics: A Critical Inquiry. Journal of Economic Issues. Pp.1045-1072.

41. Joskow PL (2003) Electricity Sector Restructuring and Comptition: Lessons Learned. Cuadernos de economía 40(121): 548-558.

42. Joskow PL (1998) Electricity Sectors in Transition. The Energy Journal 19(2): 25-52.

43. Joskow PL (1991) The Role of Transaction Cost Economics in Antitrust and Public Utility Regulatory Policies. Journal of Law, Economics \& Organisation 7: 53-83.

44. Newbery D (2006) Electricity Liberalization in Britain and the Evolution of Market Design. In Electricity Market Reform. Elsevier Global Energy Policy and Economics Series. Pp.109-143.

45. Jamasb T, Pollitt M (2005) Electricity market reform in the European Union: Review of Progress toward Liberalisation and Integration. The Energy Journal 26: 11-41.

46. Nepal R, Jamasb T (2012) Reforming the power sector in transition: Do institutions matter? Energy Economics 34(5): 1675-1682. 


\section{Civil Engineering Research Journal}

47. Landon JH (1983) Theories of vertical integration and their application to the electric utility industry. The Antitrust Bulletin 28: 101-130.

48. Michaels RJ (2004) Vertical integration: The economics that electricity forgot. Electricity Journal 17(10): 11-23.

49. Michaels RJ (2005) Rethinking vertical integration.

50. Simshauser P, Tian Y, Whish Wilson P (2015) Vertical integration in energy-only electricity markets. Economic Analysis and Policy 48(C): 35-36.

51. Meyer R (2012) Economies of scope in electricity supply and the costs of vertical separation for different unbundling cenarios. Journal of Regulatory Economics 42(1): 95-114.

52. Meyer R (2012) Vertical Economies and the Costs of Separating Electricity Supply--A Review of Theoretical and Empirical Literature. The Energy Journal 33(4): 161-185.

53. Fellows RF, Liu AMM (2009) Research Methods for Construction, John Wiley and Sons, New York, USA.

54. Tesch R (1991) Software for qualitative researchers, analysis needs and program capabilities. Using Computers in Qualitative Research, London.

55. Alves de Santana E, Da Silva Leite AL (2007) Transaction costs economics, property rights and the strategies of the firms of the Brazilian Electricity Industry.

56. http://iati.dfid.gov.uk/iati_documents/4745841.docx

57. Gratwick KN, Eberhard A (2008) Demise of the standard model for power sector reform and the emergence of hybrid power markets. Energy Policy 36: 3948-3960.
58. Inderst G, Stewart F (2014) Institutional Investment in Infrastructure in Emerging Markets and Developing Economies, Washington DC. Joskow PL (2003) Electricity Sector Restructuring and Comptition: Lessons Learned. Cuadernos de economía 40(121): 548-558.

59. Oakley J (1994) Thinking through fieldwork. In: Analysing Qualitative Data, Routledge, London.

60. Remenyi D, Williams B, Money A, Swartz E (1998) Doing Research in Business and Management: An Introduction to Process and Method. London.

61. Roumboutsos A, Pantelias A (2014) Allocating Revenue Risk in Transport Infrastructure Public Private Partnership Projects: How it Matters. Transport Reviews 35(2): 183-203.

62. Saunders M, Lewis P, Thornhill A (2009) Research Methods for Business Students ( $5^{\text {th }}$ edn,). Harlow: FT. Prentice Hall.

63. Shirley MM (2002) Experience with Privatisation: A New Institutional Economics Perspective. pp.10-31.

64. Sioshansi FP (2006) Electricity market reform: What has the experience taught us thus far? Utilities Policy 14(2): 63-75.

65. Tashakkori A, Teddlie C (1998) Mixed Methodology: Combining Qualitative and Quantitative Approaches. Thousand Oaks, CA.

66. Williamson OE (2005) Transaction Cost Economics. Handbook of New Institutional Economics. Springer: 41-65.

67. Johnson R (2001) Further reflections on Williamson's New Institutional Economics and Policy. In 45 Annual Conference of the Australian Agricultural and Resource Economics Society.

\section{Your next submission with Juniper Publishers will reach you the below assets}

- Quality Editorial service

- Swift Peer Review

- Reprints availability

- E-prints Service

- Manuscript Podcast for convenient understanding

- Global attainment for your research

- Manuscript accessibility in different formats

( Pdf, E-pub, Full Text, Audio)

- Unceasing customer service

Track the below URL for one-step submission https://juniperpublishers.com/online-submission.php 